\title{
The Alcoholism Treatment Centre in Bratislava-Dúbravka - Its Establishment and Operation
}

\author{
MOROVICSOVÁ E. ${ }^{1}$, MOROVICS, M. T. ${ }^{2}$
}

1 | Comenius University, Faculty of Medicine, and University Hospital Bratislava, Department of Psychiatry, Bratislava, Slovakia

2| Institute of History of the Slovak Academy of Sciences, Bratislava, Slovakia
Citation | Morovicsová, E., Morovics, M. T. (2019). The Alcoholism Treatment Centre in Bratislava-Dúbravka - Its Establishment and Operation. Adiktologie, 19(2), 95-104; https://doi.org/10.35198/01-2019-002-0005
BACKGROUND: In post-war Czechoslovakia, as in other countries, alcoholism was one of the gravest social problems. In addition to medical interventions, legislative and organisational measures were needed to deal with this problem, including the creation of specialised facilities for the long-term treatment of alcoholics. AIMS: To shed light on the process of the establishment and shaping of the Alcoholism Treatment Centre of the Municipal Institute of National Health in Bratislava-Dúbravka and to analyse its activities over the period 1961-1966. METHOD: This work is based on the study and content analysis of original archive materials, especially those stored at the Slovak National Archive in Bratislava, as well as focused articles from the specialist literature of the period. The authors' aim is to place the Alcoholism Treatment Centre in Bratislava-Dúbravka into the legislative and institutional developmental framework of the battle against alcoholism in Czechoslovakia and in Slovakia. RESULTS AND CONCLUSION: Since the attention of psychiatric clinics and departments was especially dedicated to the treatment of acute complications linked to alcoholism and other addictions, the establishment of specialised facilities for the long-term treatment of alcoholics was a very valuable step. The Alcoholism Treatment Centre of the Municipal Institute of National Health in Bratislava-Dúbravka was founded in 1961 by Michal Turček, MD, who headed it until 1965 . The centre, with a capacity of 25 beds, provided comprehensive healthcare to patients with an alcohol addiction. In addition to the inpatient care, the centre also included outpatient care with alcohol counselling and sobering-up centres. After the Treatment Centre closed in 1966, its inpatient section was transferred to the Regional Psychiatric Treatment Centre in Pezinok. Despite its short-lived operation, the activity of the Treatment Centre was considered to have made a positive contribution, and it represents a significant period in the development of the prevention and treatment of alcoholism in Slovakia.

\section{Keywords | Alcoholism Treatment Centre in Bratislava-Dúbravka - Alcoholism - History - 1960s - Slovakia}




\section{INTRODUCTION}

Among the many demanding tasks of healthcare in postwar Czechoslovakia - in addition to the elimination of the immediate health consequences of the war, the solution of the epidemiological situation in the country, and the overall reconstruction of the healthcare system - was a search for efficient methods of treatment for alcoholism, its prevention, and the battle against this malady. It was a complicated and geographically widespread problem with health implications but also important social dimensions, with grave consequences not only for individuals and their families but also for the whole of society. The issue of alcoholism was especially visible in some regions of Slovakia, e.g. Kysuce, Orava, in some parts of eastern Slovakia, and in Transcarpathian Ukraine, but it was basically a problem within the whole of society. Besides a system of legislative measures, the state did not have sufficiently extensive institutional facilities available with which to deal with the problem of alcoholism from the healthcare and social viewpoints. The creation of such facilities could not be expected from the activities of the Czechoslovak Temperance Association either, as such civic associations had just renewed their activities after years of subdued activity during the war. Care for alcoholics was mostly only provided by psychiatric departments and outpatient departments in some hospitals, along with a network of alcohol counselling centres which carried out their own share of the work. As a result of the Sudeten territories breaking away from Czechoslovakia in 1938, the alcohol treatment centre in Tuchlov, the only one of its kind in Bohemia and Moravia, ceased to exist. On the positive side, a progressively oriented alcohol treatment unit at the Psychiatric Department of the Faculty of Medicine of Charles University in Prague - the well-known "Apolinář", which operates to this day - commenced its activities in 1948. The continuity of this form of institutional care had likewise been interrupted in Slovakia. In 1949 the alcoholism treatment centre in Istebné ceased to exist, leaving Slovakia without any specialised institution focusing on the treatment of alcoholics. This situation persisted until the end of the 1950s. Changes only came about through the activities of the zealous psychiatrist Michal Turček, MD, a pioneer of modern methods in the battle against alcoholism in Slovakia. In 1961 he founded the Alcoholism Treatment Centre in Bratislava-Dúbravka, the chief subject matter of this study. However, this facility - unlike the alcohol treatment facility of the Prague "Apolinár" - unfortunately also ceased to operate after only a few short years.

\section{METHODOLOGY}

The article focuses on a relatively narrow segment in the historical development of healthcare in Slovakia. This is a short period of time within the evolution of the construction of institutional facilities for the treatment of alcohol addiction and solution of the issue of alcoholism in social contexts. The period of time that the contribution focuses on was determined by the first post-war decades, but its focus is the first half of the 1960s, when the Alcoholism Treatment
Centre in Bratislava-Dúbravka was in operation. Although the subject matter of the research seems, at first sight, episodical, it fits within the mosaic of the research into the battle against alcoholism and its treatment in Czechoslovakia, which has been revived in recent years in Czech and Slovak specialist journals (Šejvl \& Barták, 2017; Šejvl \& Miovský, 2018; Šejvl, Mašlániová, \& Miovský, 2019; Morovicsová \& Falisová, 2014, 2016, and others).

When working on this contribution, in the first phase we drew on our study of the contemporary and period specialist literature on the issue of alcoholism, including historically focused works of Czech and Slovak provenance. This enabled us to create an image of the battle against alcoholism in Czechoslovakia and particularly in Slovakia in the period before the establishment of the Alcoholism Treatment Centre in Bratislava-Dúbravka. At the same time we found that there was a lack of published information on this facility, which we attempted, in the crucial phase of our work, to supplement with archive materials and published works by its founder Michal Turček and his contemporaries, especially from the pages of the journal Protialkoholický obzor (Anti-Alcoholic Horizon). Archive materials, especially the relevant archives of the Slovak National Archive in Bratislava, were researched, particularly those related to the Commission of Healthcare of the Slovak National Council from 1950-1966. They included various statistics, annual reports, conceptual and strategic documents, and minutes from talks. It has to be noted that although the available archive materials provided an insight into the capacities of the various psychiatric treatment centres in the Slovakia of that period, they did not include any detailed information in relation to the facility in Bratislava-Dúbravka, although, in particular, they helped to clarify the circumstances of its origin and some of the organisational issues. We especially drew further information about the development of the facility and its achievements and methods of treatment from the works of Michal Turček. The attempt to contact some members of Dr Turček's family with the aim of gathering further information was not successful as a result of the absence of relevant materials in the possession of family members. In the interest of creating a comprehensive picture we likewise dedicated attention to the related legislative regulations and, to a slight extent, also to alcohol counselling centres, which were another important component of the battle against alcoholism of that period.

Following the organisation of the material and analysis of the content of the information acquired from the archive materials and the period specialist literature, we continued the study through a thematic-chronological interpretation that attempted to compare the Slovak developmental elements with their Czech counterparts. More extensive comparisons, thus also using foreign sources, were only used marginally because of the specific narrow focus of the contribution. 


\section{ORGANISATION AND LEGISLATIVE CONTEXT OF THE BATTLE AGAINST ALCOHOLISM IN CZECHOSLOVAKIA IN THE FIRST POST-WAR DECADES}

In May 1945 the renewed Czechoslovak state faced the demanding tasks of both the reconstruction of the economy and infrastructure that had been damaged and destroyed by the war, and, understandably, also the mitigation of the grave health-related and social consequences of the war. The prevalence of alcoholism had intensified during the war, whereas the anti-alcoholic activities of the state had, naturally, been subdued during the war. The activities of the Czechoslovak Temperance Association and its Slovak headquarters had also diminished in intensity, the latter having been transformed into the Slovak Temperance Association after the establishment of the Slovak Republic in 1939. It was necessary to revitalise these organisations and the facilities for anti-alcoholism activity quickly. As we mentioned in the introduction, the alcohol treatment facility in Tuchlov, which had held an important position in Bohemia, ceased to operate in 1938. A similar facility in Istebné in Slovakia, founded shortly before the war and having also served various purposes during the war, inter alia military ones, did not manage to develop into an institution with a more extensive and possibly country-wide operation after 1945. Initially the state could only rely on the legislative regulations related to alcoholism and, in matters of treatment, on specialised departments within psychiatric clinics or other hospitals, or possibly on revitalised or newly-formed alcohol counselling centres.

The attitudes of the state authorities and political structures to the issue of alcoholism in the first post-war decades in Czechoslovakia were, however, inconsistent - especially for ideological reasons. The ideology of the Communist Party - the chief state power - connected alcoholism, and even mental disorders, with capitalism, and expected these problems to disappear as a result of the general victory of communism. The reality was different. The number of alcoholics did not decrease, and with the passage of time the personal, family, and society-wide consequences of alcoholism could no longer be ascribed to the "capitalist enemy". Thus legislation stepped in and passed anti-alcoholism laws, as did the healthcare system, which tried to hide alcoholics behind the walls of psychiatric departments. There was a similar situation in the surrounding Soviet bloc countries, for instance in Hungary. It was characterised by the absence, or at least a lack, of specialised facilities for the treatment of alcoholism, a lack of specialists in the field, the ideologically motivated connection of alcoholism and capitalism, and the localisation of treatment to the psychiatric departments of hospitals (Elekes, 1992). The rigid and blind application of these ideological principles and, of course, the bilateral isolation of the countries of the communist bloc, especially in the 1950s, hindered the process of the search for more contemporary and efficient solutions to alcoholism as a problem within the whole of society in Hungary, as well as Czechoslovakia.
In these conditions we have to consider the foundation of the alcohol treatment unit of the Psychiatric Department of the Faculty of Medicine of Charles University in Prague, "Apolinář" (1948), to be a great achievement; under the leadership of Jaroslav Skála, MD, it significantly influenced the trends in alcohol addiction treatment, not only in Czechoslovakia, but also internationally (Hort, 2008). It was here that the first sobering-up area started up in 1951 as a new way to solve problems with alcoholics or with people strongly under the influence of alcohol. On the other hand, the inclusion of the Czechoslovak Temperance Association into the Czechoslovak Red Cross in 1950 cannot be unequivocally considered to have been a positive step. The association's activity within such a large organisation gradually grew weaker. This only began to change from the 1970s onwards, when the association gradually reasserted its independence (Ochaba et al., 2009).

In the legislative area, among the first post-war successes in the battle against alcoholism in Czechoslovakia was the adoption of Act No. 87/1948 Coll., Law on the Countering of Alcoholism, under which it was forbidden to sell or serve alcoholic drinks to people under the age of 18 and defined the role of alcoholic counselling centres, etc. (Act No. 87/1948 Coll.). Another government resolution, No. 2327/1956, contained more complex measures in the battle against alcoholism within individual sectors and social organisations. Pursuant to the aforementioned resolution, what were called "anti-alcoholism commissions" were to lead and coordinate the battle against alcoholism. But their activities brought no notable effect, as they were limited to sporadic meetings and the submission of proposals and requests (Turček, M., 1969). The unsuitable legal provisions for the battle against alcoholism were modified by Act No. 120/62 Coll., a new law in the tackling of alcoholism, which remained valid in Czechoslovakia until 1989. It defined the various forms and measures to be used in the battle against alcoholism and established the Central Anti-Alcoholism Commission as a central authority at the Ministry of Healthcare. Its role was to coordinate the methodology and organisation used in the battle against alcoholism. It submitted proposals and incentives for the development and intensification of the battle against alcoholism, checked on the implementation of anti-alcoholism measures, oversaw the work of the regional anti-alcoholism commissions, published a non-periodical journal, and organised nationwide anti-alcoholism seminars. Act No. 120/62 Coll. even stipulated the conditions that would lead to an alcoholic being ordered into compulsory treatment (Act No. 120/62 Coll.; Kácl, 1966). The Act of the Slovak National Council No. 45/1967 Coll. established a special Slovak Anti-Alcoholism Commission as the central Slovak institution in the battle against alcoholism (Act No. 45/1967 Coll.).

The general conditions for the development of healthcare in post-war Czechoslovakia were most influenced by Act No. 103/1951 on Unified Preventive and Curative Care, which stipulated the organisation of healthcare institutions and the position of psychiatric treatment facilities (Act No. 103/1951 Coll.). The law did not require the establishment of specialised alcoholism treatment centres, so the treatment 
of alcoholism mostly remained the task of the psychiatric departments of hospitals and psychiatric treatment centres.

Preventive, curative, and partly repressive care for alcoholics in Czechoslovakia was, at that time, provided by three types of healthcare facilities: sobering-up centres, alcohol counselling centres, and institutional (hospital) facilities (Kácl, 1966; Smetanová 1966).

The sobering-up centres provided care to people who, as a result of excessive consumption of alcohol, were in a state that aroused indignation in others or meant that the person was endangering themselves, their family, other people, or property. They remained in the sobering-up centre until they sobered up and, if necessary, they were provided with emergency treatment. After their release they underwent basic training on the issue of alcoholism in what were called Sunday schools and were then handed over to the registry of the alcohol counselling centre in the place of their residence. The first sobering-up centre in Czechoslovakia was created in 1951 in Prague, but their number gradually grew. An overview of the number of centres and of beds and people from 1955-1965 is provided in Table 1.

\begin{tabular}{lccc}
\hline $\begin{array}{l}\text { Type of facility and number } \\
\text { of beds }\end{array}$ & $\mathbf{1 9 5 5}$ & $\mathbf{1 9 6 0}$ & $\mathbf{1 9 6 5}$ \\
\hline Sobering-up centres & 17 & 33 & 48 \\
\hline $\begin{array}{l}\text { Number of beds at } \\
\text { sobering-up centres }\end{array}$ & 147 & 321 & 411 \\
\hline Number of people detained & 13,178 & 18,585 & 31,720 \\
\hline
\end{tabular}

Table 1 | Overview of the activity of sobering-up centres in Czechoslovakia 1955-1965

Taken from: Smetanová, 1966, p. 153

The alcohol counselling centres were dedicated to preventive activity and the provision of long-term care to people who were reported to the counselling centre by the sobering-up centres, their employers, the public security authorities, courts, or relatives, but also people who came of their own will. The number of alcohol counselling centres in the postwar decades grew markedly, as shown in Table 2.

\begin{tabular}{lcccc}
\hline $\begin{array}{l}\text { Facility and number of } \\
\text { persons registered }\end{array}$ & $\mathbf{1 9 4 9}$ & $\mathbf{1 9 5 5}$ & $\mathbf{1 9 6 0}$ & $\mathbf{1 9 6 5}$ \\
\hline $\begin{array}{l}\text { Alcohol counselling } \\
\text { facilities }\end{array}$ & 10 & 142 & 190 & 205 \\
\hline $\begin{array}{l}\text { Number of patients } \\
\text { registered }\end{array}$ & 6,000 & 39,500 & 66,500 & 87,000 \\
\hline
\end{tabular}

Table 2 | Overview of the activity of alcohol counselling centres in Czechoslovakia 1949-1965

Taken from: Smetanová, 1966, p. 153

The institutional alcohol treatment facilities provided voluntary and compulsory treatment to alcoholics within alcoholism treatment wards which formed part of the psychiatric departments of hospitals, clinics, and psychiatric treatment fa- cilities. Besides voluntary and compulsory treatment, there was also protective treatment ordered by a court for people who were often in a state of drunkenness and were committing criminal activities under the influence of alcohol.

Alcoholics and patients with an alcoholic psychosis formed about $20 \%$ of all psychiatric patients. A comparison of the sex of the patients within the psychiatric facilities is provided in Table 3.

\begin{tabular}{lcc}
\hline & Women & Men \\
\hline Czechoslovak Socialist Republic & $1.3 \%$ & $21.0 \%$ \\
\hline Czech Socialist Republic & $1.0 \%$ & $20.7 \%$ \\
\hline Slovak Socialist Republic & $2.4 \%$ & $22.7 \%$ \\
\hline
\end{tabular}

Table 3 | Representation of alcoholics in psychiatric facilities Adapted from: Turček, M., 1966b, p. 92

The state of psychiatric care in the 1950s in Slovakia (in relation to the treatment of alcoholics) is detailed in the next section.

\section{PSYCHIATRIC CARE IN SLOVAKIA IN THE 1950s AS THE BASIS FOR THE TREATMENT OF ALCOHOLICS}

Psychiatric care in Slovakia (and, as part of it, the treatment of alcoholics) - as for the whole state - was provided in three forms in the 1950s: in outpatient psychiatric departments, in hospital departments, and in psychiatric treatment facilities. Outpatient psychiatric care began to be provided in accordance with changes in the organisation of healthcare from 1952 onwards, gradually becoming the most important form of treatment. A particular drawback was the fact that it was concentrated in some cities: Bratislava, Trenčín, Nitra, Žilina, Rimavská Sobota, Košice, and Prešov. Institutional psychiatric care was provided in the psychiatric departments of hospitals and clinics and in psychiatric treatment facilities. The psychiatric departments of hospitals dealt with acute conditions

\begin{tabular}{lc}
\hline Psychiatric treatment centre (seat) & Number of beds \\
\hline Pezinok & 336 \\
\hline Vel'ké Leváre & 170 \\
\hline Čajakovo/Hronovce & 470 \\
\hline Vel'ké Zálužie & 260 \\
\hline Dolná Krupá & 150 \\
\hline Hody & 82 \\
\hline Sokolovce & 60 \\
\hline Plešivec & 299 \\
\hline Hraň & 190 \\
\hline Total & $\mathbf{2 , 0 1 7}$ \\
\hline
\end{tabular}

Table 4 | Overview of psychiatric treatment centres (PTC) in Slovakia in 1960 Adapted from: SNA, 1961a, p. 10 
through short-term hospitalisation. The overwhelming majority of beds within the hospital departments were occupied by chronic patients as a result of the lack of beds within psychiatric treatment facilities. Psychiatric treatment centres focused on providing care to what were known as the long-term ill (SNA, 1961a, p. 9). In Slovakia there were nine psychiatric treatment centres in 1960, with an overall capacity of 2,017 beds. (Table 4.)

The treatment centres were often established in repurposed buildings, e.g. in monasteries, mansions, or prisons, or sometimes in purpose-built buildings, and were located in remote, less accessible places distant from the basic medical centres, which made the provision of healthcare rather difficult. Many treatment centres had poor sanitary facilities, auxiliary premises, stores, kitchens, and premises for laboratories, X-ray workplaces, etc.

The number of patients needing institutional care gradually grew. In Table 5 there is an overview of the number of patients hospitalised in psychiatric departments and treatment centres in Slovakia from 1955-1959.

\begin{tabular}{lccc}
\hline Year & \multicolumn{3}{c}{ Overall } \\
\cline { 2 - 4 } & Admitted & Released & Died \\
\hline 1955 & 7,360 & 7,020 & 206 \\
\hline 1957 & 7,698 & 7,506 & 187 \\
\hline 1959 & 8,891 & 8,690 & 177 \\
\hline
\end{tabular}

Table $\mathbf{5}$ | Overview of hospitalisations in psychiatric departments and treatment centres in Slovakia from 1955-1959

Taken from: SNA, 1961a, p. 5

In the 1950s only one larger specialised unit existed in Slovakia that focused on the treatment of alcoholics. It was part of the psychiatric department of the hospital in Nitra, a 20-bed alcoholic treatment ward (Turček, M., 1967). Although the alcohol treatment facility in Istebné still existed in the first few post-war years, attempts to fully renew it to meet its original purpose failed (cf. Šejvl, Mašlániová, \& Miovský, 2019; Morovicsová \& Falisová, 2016).

If we take a closer look at the aims and capacities of the individual psychiatric institutions in Slovakia in the 1950s, we have to say that the institutional healthcare of alcoholics was on the poorest level. The establishment of a treatment centre that would focus on the long-term treatment of alcoholics was thus - given, inter alia, the social gravity of the issue - more than necessary.

\section{THE ALCOHOLISM TREATMENT CENTRE IN BRATISLAVA-DÚBRAVKA}

Although Slovakia had the "Apolinář" in Prague and the progressive methods of Jaroslav Skála to model its institutions on, the foundation of a similar specialised institution that would systematically dedicate itself to the treatment of alcoholics also required the creation of a suitable platform. It was necessary to find acceptable premises, build the infrastructure, and create an adequate foundation in terms of organisation and finances. Finally, it was necessary to find the staff, a team of zealous experts, headed by a highly specialised as well as ardent and relentless leading personality. These requirements were met in the person of Dr Turček, a psychiatrist who specialised in the treatment of, and battle against, alcoholism and had become one of the pioneers in this field of medicine in Slovakia. He dealt with the issues of prevention and in the institutions where he had worked he had introduced contemporary forms of ergotherapy and art therapy; he led extensive research focusing on various effects of alcohol and methods for the treatment of alcoholism, and he founded a club for recovered alcoholics. He was actively interested in the history of psychiatry, as well as the ethnological dimensions in the research of alcoholism. In 1965 he founded and, for many years, headed the specialist journal Protialkoholický obzor, which is published today under the title Alkoholizmus a drogové závislosti (Alcoholism and Drug Addictions) (Falisová, 2010; Kolibáš, 2000; Ochaba et al., 2009; Turček, K., 2011). He was the greatest contributor to the foundation and leadership of the Alcoholism Treatment Centre in Bratislava-Dúbravka, which, after the centre in Istebné ceased to operate, for a period of time filled the gap in the development in the treatment of alcoholism in Slovakia.

There were several proposals for the location and organisational structure of the future facility. In 1958 Dr Turček elaborated the specialist positions required for the creation of an alcohol treatment unit and sobering-up area which were to be located in a building on Vajnorská Street in Bratislava. The plan fell through when the proposed premises proved to be unsuitable (SNA, 1959). Another alternative was a building in what was then Leninova Street, which, according to an assessment by Dr Turček, could be suitable, but this was not realised either. Finally, premises in a recreational area about $10 \mathrm{~km}$ from the centre of Bratislava were selected for the construction of the centre (SNA, 1962a). The Alcoholism Treatment Centre in Bratislava-Dúbravka was founded by a resolution of the Municipal National Committee and the headquarters of the Municipal Institute of National Health in Bratislava. From the resolutions passed on 26 January 1961 we learn that a facility with 25 beds was to be created "outside the plan" (SNA, 1961b, p. 7), and was subsequently to be included in the network of psychiatric treatment centres (SNA, 1962b). We assume that its establishment outside the plan testifies to the persistence and tireless efforts of Dr Turček to push for the foundation of such an institution. The Alcoholism Treatment Centre was part of the network of facilities of the Municipal Institute of National Health in Bratislava and, in terms of organisation, was affiliated to the Municipal Hospital along with the Second Clinic in Bezručova Street (SNA, 1963). It began its operation in May 1961. On one hand, the location of the Alcoholism Treatment Centre in a recreational area among gardens created beneficial conditions for the patients to spend time in natural surroundings, but on the other hand the centre was relatively distant from the municipal healthcare facilities and vehicle 
access to the facility was rather complicated. Dr Turček was its chief consultant (SNA, 1962a; Turčeková, 1981).

The alcohol counselling and sobering-up centres, which already existed, were affiliated with the organisation of the newly founded Treatment Centre. The alcohol counselling centre was based at 9 Radlinského Street in Bratislava. At the time of the establishment of the Treatment Centre in Bratislava-Dúbravka it had already existed for 15 years, but it had a persistent problem, a lack of personnel and unsuitable premises (Turček, M., 1966c). The sobering-up centre with 19 beds, also in Radlinského Street, operated 24/7 (SNA, 1963). To oversee the operation of three mutually rather distant sections was demanding for the Treatment Centre management and often caused problems, especially the loss of large amounts of time. The number of inpatient beds was not expanded and it was not possible to equip them sufficiently from either a technical or staffing perspective. On the other hand, the advantage of organising three independent sections into a single workplace was that the entire anti-alcoholism activity in Bratislava was unified and followed the same methodology. The provision of healthcare was based on the experience of the department for alcoholics at the "Apolinář" Psychiatric Clinic in Prague, but several important methods could not be put into practice because the necessary specialised staff were lacking (Turček, M., 1966c). The Alcoholism Treatment Centre provided healthcare for 25 patients who were admitted voluntarily. The average period of hospitalisation was three months, but in exceptional cases it was shorter. For relapsed patients, the period of hospitalisation was even longer. Healthcare was provided to about 100 patients over the course of a year. Over the five years of operation of the Treatment Centre more than 500 patients underwent treatment, some of them more than once, and in exceptional cases several times. As the senior consultant at the Treatment Centre, Michal Turček, stated (1966d), according to estimates, about $1.5 \%$ of Bratislava's population suffered from alcoholism at that time, which, with a city population of 260,000, represented about 4000 alcoholics. If the Alcoholic Treatment Centre had a 100\% treatment success rate, with a capacity of 25 beds the successful treatment of all the alcoholics would have taken 40 years. The criteria for the selection of patients were not stipulated exactly. In many cases the senior consultant even decided to admit patients in whom a marked therapeutic effect was not expected, or in whom the degree to which their admission was voluntary could be questioned. As a rule, in such cases his motive was an effort to at least partly help the family of the patient; in other cases the admission was initiated by requests from various authorities, or through public pressure. Not even the alcohol counselling centre, which represented an integral part of the Treatment Centre, could enrol all the alcoholics. At the end of 1965 it listed 1421 patients, of whom 119 were women and eight were underage, which was a much lower number than the estimated number of alcoholics in Bratislava. According to Michal Turček's assumptions (1966c), only about 35\% of alcoholics were registered in the counselling centre.

\subsection{Therapeutic Methods for the Treatment of Alcoholism Applied in the Therapeutic Centre in Dúbravka}

Generally speaking, the basic methods in the treatment of alcoholism at that time included drug treatments and psychotherapy (Smernice, 1966). As a part of drug treatments new medicines, ataractics, which have a tranquillising and curative effect, began to be used. Their use enabled the introduction of an open-door system in the departments and a removal of the restrictions on the patients. In ergotherapy this created room for work in which the use of sharp tools could not be ruled out, e.g. work with wood, landscaping, etc. (SNA, 1961a). Psychotherapy remained an important part of the treatment, creating conditions for a psychotherapeutic influence on the patient with regard to their whole social situation, as well as the problems which caused alcoholism and resulted from it (Smernice, 1966). There were exercises that focused on the adoption of a new routine by the alcoholics, changes in lifestyle, and the development of hobbies.

The Alcoholism Treatment Centre in Bratislava made use of "apomorphine vomiting treatments" (Turček, M., 1966c, p. 105) and disulfiram, especially at the beginning of treatment, to overcome withdrawal symptoms and somatic problems. Disulfiram was also used during the patients' recovery and represented a certain kind of safeguard, which the patients perceived as a "prosthesis" (Turček, M., 1966a, p. 13). Disulfiram-alcohol tests were directed by the doctor and apomorphine treatment was carried out by nursing staff according to the doctor's instructions.

Psychotherapy as part of the treatment for alcoholism enabled the patient to achieve emotional satisfaction through the improvement of their relationships with those around them. The aim of the therapist was to help the patient to renew damaged interpersonal relationships and in the search for the true meaning of life. The application and resultant effect of psychotherapy is also effective as alcoholics especially live in the immediate present, not confronting the past and showing no interest in the future. Rewards were used to support new forms of behaviour, e.g. the therapist's attitude to the patient as a human being, relief of post-intoxication difficulties, and rewards for moderation. Other routes to satisfaction included hobbies, recreation, employment, satisfaction in the state of the family, and others (Turček, M., 1966a). Individual and group psychotherapy, led by the senior consultant, was also used in the treatment. The individual forms of psychotherapy in use included bibliotherapy, music therapy, ergotherapy, ecotherapy, and others. Bibliotherapy was carried out through reading shorter works, e.g. the "Apolináŕ Notes" (1949), and occasionally also passages from Hans Fallada's novel The Drinker, which the staff members of the facility considered more suitable than Jack London's novel John Barleycorn (Turček, M., 1966d). As the Alcoholism Treatment Centre faced a lack of technical equipment and staff, it often had to improvise in its activities. An example was the holding of a psychotherapy session with a group of 25 patients in the facility's garden. A positive aspect of this improvisation was 
the creation of better contacts with patients in comparison with psychotherapy carried out inside the facility, because the natural environment has a positive emotional influence. Ergotherapy was organised by the nursing staff according to the framework instructions from the senior consultant (Turček, M., 1966c). According to Turčeková (1981), despite less than ideal conditions the employees managed to lay the foundations for the use of psychodidactics in the treatment of mental disorders in Slovakia.

\subsection{Experience with Ecotherapy}

Following the model of Professor Jaroslav Skála and his co-workers, the senior consultant, Michal Turček, introduced not only ergotherapy but also ecotherapy into the available treatments, which he used in the countryside recovery camps organised for the patients (Turček, K., 2011). While it was in operation, the Alcoholism Treatment Centre in Bratislava-Dúbravka organised several such camps. The main goal of ecotherapy was an attempt to intensify the effect of the psychotherapy with the help of the influence of the natural environment and to teach the patients to reach subjective satisfaction without using alcohol, even though they might occasionally need to suppress their own momentary needs or feelings of displeasure. The first two-week camp for patients was organised by the employees of the Treatment Centre in a recreation centre in Bezovec in June 1964, for 49 patients. Half of the overall number of participants were current inpatients, mostly psychopaths and deprived alcoholics, and half were former patients. Financial support was provided by the Company Committee of the Revolutionary Trade Union Movement of Slovakofarma in Hlohovec. It provided transport, free-ofcharge accommodation, and a contribution to the meals. In return Slovakofarma received a benefit from the ergotherapy, which focused on various modifications and changes to the recreation centre and the local Pioneer camp. The work therapy took place for four hours a day, always in the morning. In the afternoon hobby activities took place, such as walks and various sports and games, and in the evening, there were various cultural-recreational programmes or parties around the campfire. During the first camp several trips were organised in the vicinity of the camp, e.g. to the ruins of Tematín Castle, to a mineral water spring, and to Hrádocká Valley. The staff of the camp (besides the employees of the recreational facility) consisted of a doctor, two nurses, and two administrative employees. The patients were divided into four groups based on the accommodation and work allocation, which considered their personal preferences. The group leaders were confirmed teetotallers who, with the help of other teetotal patients, also fulfilled the role of non-professional psychotherapists. During their stay the patients wrote and published a camp evening paper, Vatra (Camp Fire), produced on a typewriter, which had multiple functions: information, entertainment, and psychotherapeutic. Within the psychotherapy sessions situations were used that enabled the creation of closer contact with the patients, the conversations between the staff and patients becoming less formal and generating a feeling of warm intimacy. This approach was used from day one in the introductory group psychotherapy session and they managed to maintain it within the other sessions, around the evening campfires, and during hiking trips and discussions. The afternoon walks were also used as psychotherapy sessions for smaller groups of patients. On such occasions the doctor merely directed the discussions within the group, which were led by former patients. This approach was also applied during the morning ergotherapy. The intention of these individual forms of activities was to demonstrate to the patients the opportunities and advantages of a sober life and provide them with emotional satisfaction without the use of any euphoria-provoking substances.

When the initial experience with ecotherapy was being summarised, the maintenance of discipline by all the patients, despite the unfavourable composition of the group of inpatients, was judged positively. In his assessment, Turček (1966a, p. 15) stated that "An insubstantial increase in the number of teetotal patients was recorded among the inpatients (from 30 to 35 per cent according to the annual check)." A more marked effect was seen in former patients, in whom the experience further strengthened their teetotalism. This was manifested in a decrease in the number of people who relapsed and the fact that they maintained better contact with the club of teetotallers. This treatment in the field also created the conditions for observing the patients in various situations and thus getting to know them better, e.g. observation of their behaviour, verbal expressions, gestures, etc., during the group campfires. It was then possible to use this information within the individual psychotherapy sessions. The contribution of the ecotherapy was also viewed positively by the administrative employees of the Treatment Centre, who in this way had an opportunity to gain a better understanding of the issue of alcoholism and alcoholic patients, which also contributed to a better understanding of the issues in the overall treatment and support of the facility's activities after their return from the camp. A negative feature of the ecotherapy mentioned by the employees was the inappropriate behaviour of some patients as a result of changes in their personality. E.g. during the group campfires these patients could not control themselves well and easily slipped into impoliteness and coarseness, and had more difficulty following the rules of games and friendly entertainment activities. In fact, they only pretended to participate in the joint activities, but at the end of the day presented themselves as having met an egotistical goal of personal satisfaction by shouting over others and drawing attention to themselves. There were cases when some patients refused to participate in the joint activities, but with the correct motivation they understood the intention of the activities, not only for themselves but also for those around them. An example of this was a statement by a patient who had at first refused to take part in a joint trip, but afterwards said enthusiastically: "I'd never have believed that a walk could be so nice. I've got to have such an experience with my family. I didn't know how to live before." (Turček, M., 1966a, p. 15).

As early as September 1964, the facility employees organised another week-long camp in tents on a large Danubian lake and the following year, in June and September 1965, other rehab camps in Bezovec. 


\section{DISCUSSION AND CONCLUSION}

The location and the facilities at the Alcoholism Treatment Centre were far from ideal and the Centre was never completed according to the original plan. Nevertheless, it contributed to the improvement of the state of health of hundreds of patients, as well as to the solution of the grave social problems suffered by families. After it had been operating for five years, the chief consultant Michal Turček summarised his experience with the facility and its results in an article in the journal Protialkoholický obzor (Turček, M., 1966c). In the absence of other archive data - in the current state of the research - this article provides some interesting information about the effectiveness of the treatment, although it is, to a certain extent, probably subjective as it was written by the founder and leading personality of the institution. According to Turček, about 30\% of the patients maintained a teetotal lifestyle for at least one year; however, a certain number of them relapsed shortly after this point. This phenomenon may have been related to the symbolic resolution of the patients to "last at least one year". At the time of the evaluation, considering the period of time from the foundation of the facility to date, less than $20 \%$ of the patients had already abstained for a period of more than one year and some had done so for as much as five years. In relation to their social environment, Turček saw positive progress for married patients in their family life, an improvement of the situation at their workplace, a decrease in the psychopathic features of their personality, and the expansion of their hobby activities. In terms of cooperation, he evaluated positively the patients' active interest in their treatment, the degree to which they were critical, and the accuracy of their view of the situation, as well as their openness to cooperate with the alcohol counselling centre or the therapeutic club in the process of recovery. The interest and cooperation of family members during the process of treatment also had a great positive effect.

Ineffective treatment was often due to the attitude of the patient towards the treatment, with often deliberately negative tendencies which were sometimes already visible whilst they were still in hospital, but in other cases not until the end of their hospital stay. Those patients who did not have the correct attitude in advance set some kind of deadline for being teetotal - as a rule until an improvement in their state of health. Other patients exhibited the attitude that they were the victim and expected special appreciation and admiration from their family for the "sacrifice" they had made (Turček, M., 1966c). If the family did not show the expected degree of admiration, they returned to the company of their drunken ways, where they loudly proclaimed their teetotalism until a relapse occurred. Relapses were also caused by feelings of disability in the teetotal patient, who wanted to be back on a par with their friends and acquaintances in terms of drinking and to belong again to the section of society from which they were excluded as a teetotaller. Peer pressure had a very important role to play in this, particularly pressure from their wives. The failure of the treatment or ineffective treatment could also have been due to the deficiencies, incompleteness, and limited possibilities of the
Treatment Centre, a lack of specialised staff, psychotherapy in groups that were too large, the inability to apply certain progressive methods, etc., which were also pointed out by Dr Michal Turček.

Besides treatment, the inpatient department, in cooperation with the alcohol counselling centre and the sobering-up centre, also carried out preventive and enlightenment activities. In the field of healthcare education the employees of the individual sections gave lectures, took part in discussions and radio and TV programmes, and contributed to publications and the creation of leaflets and booklets that focused on countering alcoholism. Through an initiative by the employees of the Alcoholism Treatment Centre, a teetotallers' club was founded in 1962, after many difficulties. It was organised as part of the alcoholic counselling centre and represented a form of outpatient recovery. Its main role was to maintain contact with former patients and influence them psychotherapeutically. The club members met regularly and organised various programmes in which the senior consultant of the Treatment Centre also took part (Turčeková, 1981).

The initiative to start publishing the journal Protialkoholický obzor in 1965 was, to a certain extent, based on the experience of the Treatment Centre in Bratislava. It went on to become the most important specialist publication focused on the prevention and treatment of alcoholism in Slovakia. This was to a decisive extent thanks to its initiator and chief editor for many years, Dr Michal Turček.

The Alcoholism Treatment Centre in Bratislava-Dúbravka was led by Dr Turček until 1965, when he began to work at the Regional Psychiatric Treatment Centre in Pezinok (Falisová, 2010). But he continued to work with the Treatment Centre in Dúbravka, as well as the alcohol counselling centre in Bratislava, and directed the methodology used in the activities of these institutions. He developed his professional activity fully as a senior consultant in Pezinok, where he introduced a whole range of progressive methods into the treatment regime, art therapy being among them (Kolibáš, 2000).

The Alcoholism Treatment Centre in Bratislava-Dúbravka ceased to operate in 1966, when it was abolished through a resolution of the Healthcare Committee of the West Slovak Regional National Committee in October of that year. It was reorganised and became a children's psychiatric sanatorium (Turčeková, 1981). The related documents do not list the precise reasons for this change. We assume that it was part of the overall restructuring of the network of healthcare facilities, with further pressure coming from the need to find a place for the children's psychiatric sanatorium. The 25 beds of the facility were transferred to the Regional Psychiatric Treatment Centre in Pezinok, where in 1967 - again headed by Dr Turček - a 42-bed sub-department was created for the voluntary and compulsory treatment of alcoholics. 
Authors' contribution: Eva Morovicsová carried out the search and listing of the primary excerpts of the source documents and their sorting, analysis, and processing. Miroslav Tibor Morovics contributed to the analysis and processing of the source materials. The authors cooperated closely on the final concept of the article and final technical modifications.
Declaration of interest: No conflict of interest.

\section{REFERENCES}

Elekes, Zs. (1992). The Development of an Alcohol Treatment System in Hungary. In H. Klingemann, J.-P. Takala, \& G. Hunt (eds.). Cure, Care, or Control: Alcoholism Treatment in Sixteen Countries. Albany: State University of New York Press, pp. 23-37.

Falisová, A. (2010). Lekári na Slovensku do roku 2000. [Physicians in Slovakia to 2000] Bratislava: Veda.

Hort, V. (2008). Doc. MUDr. Jaroslav Skála, CSc. - jeho historický vklad a poselství pro současnost. [Doc. MUDr. Jaroslav Skála, CSc - His Historical Contribution and Legacy] Česká a slovenská psychiatrie, 104 (3), 138-139.

Kácl, K. (1966). Problematika alkoholismu v Československu. [The Issue of Alcoholism in Czechoslovakia] Protialkoholický obzor, 1(4), 110-114.

Kolibáš, E. (2000). Pred tridsiatimi rokmi zomrel primár MUDr. Michal Turček, zakladatel' časopisu Alkoholizmus a drogové závislosti (Protialkoholický obzor). [Chief Physician MUDr. Michal Turček, Founder of the Journal Alkoholizmus a drogové závislosti (Protialkoholický obzor), Died 30 Years Ago] Alkoholizmus a drogové závislosti, 35(2), 65-66.

Morovicsová, E., \& Falisová, A. (2014). Právne normy a činnost' Československého abstinentného zväzu v boji proti alkoholizmu v prvej Československej republike. [Legal Norms and the Activities of the Czechoslovak Temperance Association in the Battle Against Alcoholism in the First Czechoslovak Republic] Alkoholizmus a drogové závislosti, 49(2), 65-80.

Morovicsová, E., \& Falisová, A. (2016). Význam protialkoholických liečební $\checkmark$ boji proti alkoholizmu v prvej Československej republike. [The Importance of Alcoholism Treatment Centres in the Battle against Alcoholism in the First Czechoslovak Republic] Česká a slovenská psychiatrie, 112 (6), 287-297.

Ochaba, R., Rovný, I., \& Bielik, I. (2009). Ochrana detí a mládeže. Tabak, alkohol a drogy. [Protection of Children and Youths. Tobacco, Alcohol and Drugs] Bratislava: Úrad verejného zdravotníctva Slovenskej republiky.

Smernice (1966). Smernice pre zriadovanie a činnost protialkoholických poradní a metodické pokyny pre činnost protialkoholických poradní. [Directives for the Establishment and Activities of Alcohol Counselling Centres and Methodological Guidelines for the Activities of Alcohol Counselling Centres] Protialkoholický obzor, 1(1), 28-34.

Smetanová, Z. (1966). Organisace preventivní a léčebné péče o alkoholiky v ČSSR. [The Organisation of Preventive and Curative Care for Alcoholics in the Czechoslovak Socialist Republic] Protialkoholický obzor, 1(5), 153-154.

SNA (1959) = Slovenský národný archív (dalej len SNA), fond (dálej len f.) Povereníctvo Slovenskej národnej rady pre zdravotníctvo (d’alej len SNR-Z). [Slovak National Archive (hereinafter SNA, archive (hereinafter f.) Commission of the Slovak National Council for Healthcare (hereinafter SNR-Z)] Ústredný národný výbor v Bratislave, odbor zdravotnícky. Objekty pre protialkoholické oddelenie a záchytnú stanicu adresované Povereníctvu zdravotníctva, č. 103/59, z 15.1.1959, kartón č. (d'alej len k. č.) 505. [Central National Committee in Bratislava, Healthcare Department. Premises for Alcohol Treatment Units and Sobering-Up Areas, Addressed to the Commission for Healthcare]

SNA (1961a) = SNA, f. Povereníctvo SNR-Z. Zpráva o previerke psychiatrických liečební a návrh opatrení na zlepšenie psychiatrickej služby na Slovensku,1.1961 k. č. 2. [Report on the Inspection of Psychiatric Treatment Centres and a Proposal of Measures for the Improvement of the Psychiatric Service in Slovakia]

SNA (1961b) = SNA, f. Povereníctvo SNR-Z. Zdravotnícka komisia Mestského národného výboru v Bratislave, 26.1.1961. Komplexné rozbory za rok 1960, č. Zdrav. 70/1961, k. č. 24. [Healthcare Commission of the Municipal National Committee in Bratislava, 26 January 1961. Detailed Analyses of 1960]
SNA (1963) = SNA f. Povereníctvo SNR-Z. Zpráva o výsledku straníckohospodárskej previerky riadenia a úrovne zdravotnej starostlivosti v meste Bratislava, k. č. 57. [Report on the Result of the Party-Economic Inspection of the Management and Level of Healthcare in the City of Bratislava]

SNA (1962b) = SNA, f. Povereníctvo SNR-Z. Správa o plnení plánu rozvoja zdravotníctva na Slovensku v roku 1961 zdravotníckymi zariadeniami spravovanými národnými výbormi. Plán siete, 10.3.1962, č. Z-10912/1962-VI/9, k. č. 4. [Report on the Fulfilment of the Plan for the Development of Healthcare in Slovakia in 1961 by Healthcare Facilities Managed by National Committees. Plan of the Network]

SNA (1962a) = SNA, f. Povereníctvo SNR-Z. Zápis z jednania so s. dr. Jozefom Pogádym, CSc., riaditel'om KPL v Pezinku, krajským odborníkom Západoslovenského kraja Bratislava, 9.1.1962, k. č. 3. [Minutes from Talks with Dr. Jozef Pogády, CSc, Director of the Regional Psychiatric Treatment Centre in Pezinok, regional specialist for the West Slovakia Region, Bratislava, 9 January 1962

Šejvl, J., \& Barták, M. (2017). Počátky ústavní léčby závislosti na alkoholu v českých zemích počátku 20. století v kontextu veřejného zdravotnictví. [The Beginnings of Institutional Treatment of Alcohol Addiction in the Regions of Bohemia in the Early 20 ${ }^{\text {th }}$ Century in the Context of Public Healthcare] Adiktologie, 17(4), 272-280.

Šejvl, J., Mašlániová, M., \& Miovský, M. (2019). The Oldest Addiction Treatment Institution on the Historical Territory of Slovakia: The Istebné nad Oravou Treatment Facility (1937-1949). Adiktologie, 1(19), 17-25.

Šejvl, J., \& Miovský, M. (2018). The First Inpatient Alcohol Treatment Facility in the Czech Republic: case study of the Tuchlov institution (1923-1938). Adiktologie, 18(2), 97-104.

Turček, K. (2011). Nedožité devätdesiatiny zakladatelá časopisu Protialkoholický obzor, primára MUDr. Michala Turčeka. [The $90^{\text {th }}$ Anniversary of the Birth of the Founder of the Journal Protialkoholický obzor, Senior Consultant MUDr. Michal Turček] Alkoholizmus a drogové závislosti, 46(3), 185-187.

Turček, M. (1966a). Skupinová psychoterapia v prírode. [Group Psychotherapy in Natural Surroundings] Protialkoholický obzor, 1(1), 13-15.

Turček, M. (1966b). Poznámky k problematike boja proti alkoholizmu na Slovensku. [Notes on the Issue of Battling Alcoholism in Slovakia] Protialkoholický obzor, 1(3), 90-95.

Turček, M. (1966c). Pät rokov Protialkoholickej liečebne MÚNZ Bratislava v Dúbravke. [Five Years of the Alcoholism Treatment Centre of the Municipal Institute of National Health Bratislava in Dúbravka] Protialkoholický obzor, 1(3), 104-106.

Turček, M. (1966d). Umenie a alkoholizmus. [Art and Alcoholism] Protialkoholický obzor, 1(4), 145-150.

Turček, M. (1967). Niekol'ko dát o situácii v boji proti alkoholizmu na Slovensku. [Some Information on the Situation in the Battle against Alcoholism in Slovakia] Protialkoholický obzor, 2(2), 33-38.

Turček, M. (1969). Kritický pohlad na náš boj proti alkoholizmu. [A Critical View of Our Battle against Alcoholism] Protialkoholický obzor, 4(3), 75-81.

Turčeková, V. (1981). Prvých pät rokov Protialkoholickej liečebne MúNZ v Bratislave- Dúbravke. [The First Five Years of the Alcoholism Treatment Centre of the Municipal National Health Institution in Bratislava-Dúbravka] Protialkoholický obzor, 16(3), 185-187. 
Zákon č. 120/1962 Sb. = Zákon č. 120 ze dne 19. prosince 1962 o boji proti alkoholismu. [Act No. 120 of 19 December 1962 on the Battle against Alcoholism] Sbírka zákonů Československé socialistické republiky, ročník 1962, částka 65, vydána dne 27. prosince 1962, 587-590.

Zákon č. 103/1951 Sb. = Zákon č. 103 ze dne 19. prosince 1951 o jednotné preventivní a léčebné péči. [Act No. 103 of 19 December 1951 on Unified Preventive and Curative Care] Sbírka zákonů republiky Československé, ročník 1951, částka 50, vydána dne 27. prosince 1951, 265-268.

Zákon č. 87/1948 Sb. = Zákon č. 87 ze dne 15. dubna 1948 o potírání alkoholismu. [Act No. 87 of 15 April 1948 on the Countering of Alcoholism] Sbírka zákonů a nařízení republiky Československé, ročník 1948, částka 35, vydána dne 4. května 1948, 801-803.

Zákon č. 45/1967 Zb. = Zákon Slovenskej národnej rady č. 45/1967 Zb. z 26. apríla 1967 o Protialkoholickom zbore na Slovensku. [Act of the Slovak National Council No. 45/1967 Coll. of 26 April 1967 on the Anti-Alcoholism Commission in Slovakia] 